\title{
Elementos de coerência textual
}

\section{Resumo}

Este artigo analisa alguns dos fatores que afetam a coerência de um texto. Com linguagem simples e farta exemplificação, procura mostrar que produtor e receptor devem ter conhecimentos comuns e dominar regras para que o texto não pareça sem sentido. Escritores e leitores devem ficar atentos à situação de comunicação, ao contexto, ao gênero, à intertextualidade, ao léxico, ao nível de linguagem, à organização narrativa, aos argumentos, à sintaxe, à concretização dos temas e à organização temporal. Esses elementos concorrem para que um texto seja coerente e, por isso, merecem toda a atenção de quem escreve e de quem lê.

\section{Abstract}

This article analyzes some of the factors affecting the coherence of a text. Using simple language and several examples, it tries to show that both producer and receptor must to have knowledge in common, as well as to master rules, so that the text seems meaningful. Both those people writing and the ones reading texts must pay attention to the situation where the communication is to happen, and also to the context, gender, relationship among texts, vocabulary, level of language, organization of the text, arguments, syntax, the real making of the text and its time organization. All those elements contribute to the coherence of a text. Therefore, everyone who writes or reads should pay attention to them.

Não detalharemos as nuances metodológicas e terminológicas dos estudos de coerência textual, pois não nos dirigimos a lingüistas.
Procuraremos mostrar, com comentários simples e farta exemplificação, os fatores que interferem diretamente na percepção da coerência de um texto. O leitor que desejar se aprofundar no assunto - até para discutir algumas de nossas observações e escolhas -, encontrará, na bibliografia, material suficiente para iniciar sua pesquisa.

É comum ouvirmos que um determinado texto é confuso, sem sentido, um verdadeiro "samba do crioulo doido". Às vezes, também escutamos o contrário: o texto é bem elaborado, bem escrito, as idéias são claras, compreensíveis, um primor. Essas impressões de clareza ou obscuridade estão relacionadas à possibilidade de se atribuir sentido àquilo que lemos, isto é, de considerarmos um determinado texto coerente ou não.

Koch e Travaglia afirmam que a noção da coerência "está diretamente ligada à possibilidade de se estabelecer um sentido para o texto, ou seja, ela é o que faz com que o texto faça sentido para os usuários, devendo, portanto, ser entendida como um princípio de interpretabilidade, ligada à inteligibilidade do texto numa situação de comunicação e à capacidade que o receptor tem para calcular o sentido deste texto". (1997, p. 21; grifos nossos)

Segundo esses autores, a coerência não só decorreria da articulação de partes do texto (da relação entre palavras, frases, parágrafos etc.), mas também do grau de interação, de conhecimento e de competência dos interlocutores para elaborar e interpretar as mensagens que recebem e, é claro, enviam.

Considerando coerência como possibilidade interpretativa, podemos inferir que leitores diferentes podem perceber diferentemente o sentido de um texto. A esse respeito, Koch e Travaglia dizem que a capacidade de recuperar o sentido de

*Mestre em Letras - Departamento de Lingüística da Faculdade de Filosofia, Ciências e Letras da Universidade de São Paulo. Professor de Língua Portuguesa do curso de Pedagogia das Faculdades Integradas “Campos Salles” e da UniSant'ana. 
um texto "pode ter limites variáveis para o mesmo usuário, dependendo da situação de comunicação e, para usuários diversos, dependendo de fatores vários (como grau de conhecimento sobre o assunto, grau de conhecimento de um usuário pelo outro, conhecimento de recursos lingüísticos utilizados, grau de integração dos usuários entre si e/ou no assunto etc.)". (1997, p. 32, grifos nossos)

A coerência, portanto, está subordinada à competência dos leitores/ouvintes de recuperar o sentido de um texto e - no que diz respeito à produção da competência dos escritores/falantes de produzir textos que possam ter seu sentido recuperado.

Feita essa curta introdução, podemos analisar alguns exemplos e verificar concretamente como os fatores citados acima - situação de comunicação, grau de conhecimento do assunto etc. afetam a percepção do sentido de um texto.

Comecemos com A vaguidão específica, de Millôr Fernandes.

\section{A Vaguidão Específica}

"As mulheres têm uma maneira de falar que eu chamo de vago-específica".

(Richard Gehman)

- Maria, ponha isso lá fora em qualquer parte.

- Junto com as outras?

- Não ponha junto com as outras, não. Senão pode vir alguém e querer fazer qualquer coisa com elas. Ponha no lugar do outro dia.

- Sim senhora. Olha, o homem está aí.

- Aquele de quando choveu?

- Não, o que a senhora foi lá e falou com ele no domingo.

- Que é que você disse a ele?

- Eu disse para ele continuar.

- Ele já começou?

- Acho que já. Eu disse que podia principiar por onde quisesse.

- É bom?

- Mais ou menos. O outro parece mais capaz.
- Você trouxe tudo pra cima?

- Não senhora, só trouxe as coisas. O resto não trouxe porque a senhora recomendou para deixar até a véspera.

- Mas traga, traga. Na ocasião, nós descemos tudo de novo. É melhor senão atravanca a entrada e ele reclama como na outra noite.

- Está bem, vou ver como.

Se o escritor pensou que existiria um leitor capaz de compreender o diálogo entre as duas mulheres, certamente se equivocou. Maria e a senhora estão falando de quê? Para nós, a conversa não tem sentido, ou seja, é incoerente. Para as duas mulheres, no entanto, tudo que dizem é coerente, pois compartilham um conhecimento que nós, leitores, não temos: elas conhecem a situação de comunicação e sabem o significado de partes, lá em cima, lugar de outro dia, coisas, para cima, resto, outras, lá etc. E um escritor competente como Millôr Fernandes, se quisesse que compreendêssemos o diálogo, forneceria pistas para que soubéssemos o que as duas senhoras sabem. Teria descrito o ambiente em que elas estão, teria fornecido dados a respeito das personagens e sobre as tarefas que estão realizando. Como não o fez, queria que o diálogo parecesse incoerente.

Essa incoerência ganha sentido quando consideramos o título, a epígrafe e outros textos do autor $^{1}$ - quase sempre críticos e humorísticos. Esses elementos nos permitem perceber o provável sentido do texto: uma crítica bemhumorada ao modo de falar das mulheres. O diálogo entre Maria e a senhora é o exemplo de que as pessoas do sexo feminino falam mesmo de uma maneira "vago-específica". A vaguidão presente no diálogo faz parte desse sentido que Millôr pretendia veicular na interlocução com o leitor. Por isso, podemos afirmar, por paradoxal que seja, que a coerência do diálogo que Maria e a senhora travam está justamente na sua incoerência.

O conhecidíssimo Samba do crioulo doido, de Sérgio Rangel Porto, também é um caso em que

\footnotetext{
${ }^{1}$ Se quiser conhecer melhor Millôr e seus textos pode visitar o site do escritor Millôr Online - Enfim um Escritor sem Estilo: http://www.uol.com.br.millor.home.htm
} 
a incoerência das mensagens tem função de dar coerência ao texto.

\section{Samba do crioulo doido}

Foi em Diamantina / Onde nasceu JK

Que a princesa Leopoldina / Arresolveu se casá Mas Chica da Silva / Tinha outros pretendentes

E obrigou a princesa / A se casar com Tiradentes

Lá iá lá iá lá iá / O bode que deu vou te contar

Joaquim José / Que também é Da Silva Xavier

Queria ser dono do mundo / E se elegeu Pedro II

Das estradas de Minas / Seguiu pra São Paulo

E falou com Anchieta / O vigário dos índios

Aliou-se a Dom Pedro / E acabou com a falseta

Da união deles dois / Ficou resolvida a questão

E foi proclamada a escravidão / E foi proclamada a escravidão

Assim se conta essa história / Que é dos dois a maior glória

$D^{\underline{a}}$ Leopoldina virou trem / E D.Pedro é uma estação também

O, ô, ô, ô, ô, ô / O trem tá atrasado ou já passou

Relacionando essa letra de samba-enredo aos episódios históricos nela referidos, temos de considerá-la incoerente. Juscelino Kubitschek pode até ter nascido em Diamantina, mas a princesa Leopoldina não se casou com Tiradentes, a escravidão não foi proclamada e não houve eleição para imperador. Numa prova de História do Brasil, por exemplo, esse texto mereceria um sonoro zero. No entanto, levando em conta o gênero do texto - letra de música popular -, conhecendo o autor e suas produções - Porto possuía, como Millor, uma veia humorística bem desenvolvida -, notamos, como também percebeu o famigerado cronista esportivo Juarez Soares, que Sérgio Porto "imaginou um compositor crioulo que tomou umas e outras e resolveu escrever a letra de um samba enredo. Já meio quente pelos gorós, o crioulo misturou tudo. O episódio da descoberta do
Brasil com proclamação da República, grito da Independência, e nascimento de Juscelino Kubitschek". Misturou tanto que desse samba nasceu a expressão "samba do crioulo doido", que até hoje é sinônimo de confusão. Juarez Soares, por exemplo, usou-a para se referir à confusão que reinou na partida da seleção brasileira contra o Paraguai no mês de julho de 2001.

A análise rápida desses dois exemplos mostra que só recuperamos o sentido de um texto se conhecermos:

\section{A situação de comunicação}

Um texto pode parecer absurdo ao leitor que não conhece a situação em que foi produzido. No texto de Millôr, por exemplo, o diálogo entre a patroa e a empregada só faz sentido para elas. Para nós, que não conhecemos os detalhes da situação, o diálogo é incoerente.

Este outro exemplo, inspirado nos comentários da página 47 do livro de Koch e Travaglia, também ilustra a importância de se conhecer a situação de comunicação, para que possamos atribuir sentido ao texto:
A: Júlia terá dor de dentes.
$B$ : Júlia está chorando de dor.
A: Bingo!

A incoerência desses enunciados desaparece, se imaginarmos a seguinte situação: A é dentista e irmão de Júlia; conhece bem as cáries da irmã. Júlia está comendo doces e A diz "Júlia terá dor de dentes". Ninguém da família se preocupa. Mais tarde, Júlia reclama e B - outro membro da família - diz "Júlia está chorando de dor". O irmão dentista, então, afirma "Bingo!", significando que a dor era certa e esperada.

\section{$\mathrm{O}$ gênero a que o texto pertence}

Tanto o texto de Millôr quanto o de Sérgio Porto são coerentes, respectivamente, como 
crônica de costumes e como letra de música popular, mas não fazem nenhum sentido como dissertações de mestrado (a não ser, é claro, que se queira criticar a comunidade acadêmica). Relacionar o texto e o gênero é importante para que possamos recuperar o significado, principalmente se o texto se referir a outras "realidades". Vejamos um exemplo:

A panela de ferro propôs à de barro que empreendessem uma viagem. Esta, alegando que the seria mais conveniente ficar sobre o fogão, pois era muito frágil e o menor esbarrão seria o suficiente para quebrá-la, recusou-se à façanha.

- Tu és feita de material mais resistente e podes aventurar, na certeza de que nada te pode causar dano - explicou a convidada.

Esse trecho de uma fábula de La Fontaine mostra que a coerência de um texto está estreitamente ligada ao gênero a que pertence. Panelas não viajam e não falam, mas basta que consideremos o gênero fábula, para que tudo se torne compreensível.

Engendrar mundos é uma das mais importantes propriedades da linguagem. E há textos que têm como princípio de construção a criação de universos; ficção científica, contos de fada, mitos, discurso religioso etc. são exemplos de que a lógica da nossa experiência não tem valor em certas ocasiões. Panelas, formigas e cigarras não falam; nem mesmo sabemos se o planeta Vulcano existe. Isso não impede, porém, que consigamos compreender as panelas conversando nas Fábulas de La Fontaine. Também não impede que consideremos coerente a presença do Dr. Spock no seriado Jornada nas Estrelas.

\section{$\mathrm{O}$ contexto}

Contexto está sendo entendido aqui do ponto de vista lingüístico: "unidade lingüística maior, responsável pela atribuição de sentido a uma unidade menor que está inserida nela: assim, a frase constitui o contexto da palavra, o texto o da frase etc." (Fiorin e Savioli, 2000).
No texto de Millôr, o diálogo entre as duas mulheres só é coerente se considerarmos o título, a epígrafe, o livro em que ele está (um livro com outros textos de características semelhantes). Apresentado sem esses elementos, o diálogo não teria sentido e nem mesmo graça.

Vejamos dois exemplos:

1. Criem separados uma dúzia de frangos, cujo único alimento consista de titela de cágado, cozida ou cevada: esse alimento deverá ser sempre fresco.

Diariamente cozinhe-se um frango em pouca água, até desmanchar.

Em seguida esprema-se a carne, que saia todo o suco; coem o caldo e levem-no novamente à panela com uma colher de açúcar rosado (mascavo). Deixase ferver um pouco, coa-se novamente, e estará o caldo pronto.

2. Tomem os pombinhos já limpos e dêem-lhes uns cortes na carne, colocando dentro fatias de toucinho. Temperem-nos a gosto, levando-os ao fogo, a cozer.

Façam a massa de pastelão e coloquem dentro os pombinhos, com caldo de vaca, de carneiro ou de galinha, e um pouco de agraço ou caldo de limão. Cubram tudo com a mesma massa do pastelão, e levem ao forno brando. (sic)

Ao ler os textos, percebemos que são receitas: o primeiro de caldo de frango e o segundo de pastel de pombo.

Soam estranhas, no entanto, algumas ordens: criar separado uma dúzia de frango alimentados com titela de cágado? Pegar os pombinhos? Hoje, criar frango já é um luxo de poucos, quanto mais alimentados com titela de cágado. Pastel de pombo, então, nem pensar. Se tivermos que matar pombos para recheio de pastéis ou cágados para alimentar frangos, estaremos arriscados a ser presos por crime ambiental.

Algumas palavras também não são muito comuns aos nossos ouvidos: titela, agraço?

Segundo o Aurélio, titela vem do latim titella, que é diminutivo de titta = 'teta'. Em português, titela nomeia "a parte carnuda do peito da ave" e, por extensão "coisa preciosa, ou a melhor parte de 
qualquer coisa”. Titela de cágado seria, portanto, a parte mais carnuda desse simpático animal.

Agraço deriva da palavra latina acer que significa "agudo", "azedo"; "forte", "vigoroso" e nomeia "o suco de uva verde" ou de "qualquer fruta muito acre".

Essas informações ajudam, mas não resolvem. Só se pode compreender o sentido desses dois textos, se os contextualizamos.

Comecemos pelos títulos:

A primeira receita tem como título FRAN. GOS PARA OS HÉCTICOS, isto é, para tísicos ou tuberculosos. A segunda receita é intitulada singelamente PASTÉIS DE POMBINHOS. Este título confirma o que havíamos inferido e aquele ajuda a compreender o porquê da necessidade de alimentar os frangos com titela de cágado. Quem já conviveu no interior ou nas regiões litorâneas sabe que, até hoje, parte da população já usou ou ainda usa tartarugas e seus derivados para tratar doenças pulmonares.

Com os títulos compreendemos melhor, mas não resolvemos dois problemas: não se pode sair por aí matando pombos e cágados; muito menos tratando tuberculose com caldinho. Os textos, portanto, ainda são incoerentes para nós, citadinos leitores do século XXI.

Se, no entanto, contextualizarmos os textos na obra - Um tratado da cozinha portuguesa do século XV [Coleção de receitas, algumas bastante originais, para o preparo das mais variadas iguarias] - a coerência se restabelece. No século XV, tratar tísicos com caldo de frangos criados em casa e alimentados com titela de cágados e caçar pombos para fazer pastéis era perfeitamente coerente.

\section{$\mathrm{O}$ intertexto}

O texto de Millôr e o samba de Porto fazem mais sentido, quando relacionados a textos dos próprios autores. Por isso é preciso que o leitor tenha um repertório de leituras que permita que ele estabeleça relações entre textos; relações muitas vezes explicitadas nos próprios textos, como neste poema de José Paulo Paes:

\section{Canção do exílio facilitada}

LÁ?

$\mathrm{AH}$ !

SABIÁ...

PAPÁ...

MANÁ...

SOFÁ...

SINHÁ...

CÁ?

$\mathrm{BAH}$ !

O título do poema de Paes remete claramente à famosa "Canção do Exílio" de Gonçalves Dias:

Minha terra tem palmeiras,

Onde canta o sabiá;

As aves, que aqui gorjeiam,

Não gorjeiam como lá.

Nosso céu tem mais estrelas,

Nossas várzeas têm mais flores,

Nossos bosques têm mais vida,

Nossa vida mais amores.

Em cismar, sozinho, à noite,

Mais prazer encontro eu lá;

Minha terra tem palmeiras,

Onde canta o sabiá.

Minha terra tem primores,

Que tais não encontro eu cá;

Em cismar - sozinho, à noite -

Mais prazer encontro eu lá;

Minha terra tem palmeiras,

Onde canta o sabiá.

Não permita Deus que eu morra

Sem que eu volte para lá;

Sem que desfrute os primores

Que não encontro por cá;

Sem qu'inda aviste as palmeiras,

Onde canta o sabiá.

Dias escreveu seu texto em julho de 1843 , em 
Coimbra, onde vivia um exílio físico e geográfico. Como se pode observar, o texto do poeta romântico constrói a imagem de uma terra exuberante, onde tudo é melhor: o trinado dos pássaros é mais suave; as flores, as estrelas e os amores são mais abundantes; e os bosques, com suas palmeiras, são mais vivos.

Numa crítica aos exageros românticos de Dias, Paes "facilita" a expressão do paraíso. Ele trata do exílio em sua essência. O que importa é que a satisfação - AH! - está LÁ: o lugar de onde se saiu e onde estão todas as coisas de que se gosta (sabiá, papá, maná, sofá, sinhá). CÁ, “o lugar onde reside o exilado", só há enfado, insatisfação, descontentamento - BAH!. O autor elabora um texto extremamente sintético, cuja leitura só tem sentido se se levar em conta o poema de Gonçalves Dias.

Até este ponto, vimos que a coerência decorre de complexas relações do texto com o contexto, com outros textos, com a situação de comunicação e com o gênero. Relações que devem ser observadas tanto por escritores quanto por leitores. Dar um sentido ao texto, relacionado-o ao contexto, a outros textos, à situação, ao gênero, não é competência somente de quem lê. $\mathrm{O}$ escritor também precisa ficar atento a todos esses aspectos, caso contrário pode não ser compreendido.

Poderíamos dizer que o tipo de coerência de que tratamos até aqui é "externa", pois - exceto no que diz respeito ao título - o sentido do texto surge de relações que ultrapassam os limites das palavras, frases e parágrafos.

Todos sabemos, porém, que o sentido do texto também depende da adequação de suas partes "internas". Segundo Fiorin e Savioli, "quando se fala em coerência, pensa-se na não-contradição de sentidos entre passagens do texto, na existência de uma continuidade semântica", isto é, todas as partes do texto têm de relacionar de maneira que o leitor/ouvinte possa atribuir sentido a ele (2000, p.396).

Se considerarmos a relação entre palavras, frases e parágrafos, podemos dizer que há vários elementos que afetam a coerência. Tratemos de alguns deles.

\section{A seqüência narrativa}

A maneira como as partes de uma narrativa se relacionam é importantíssima para que haja coerência. Uma ação, por exemplo, só poderá ser realizada se a personagem for competente, isto é, puder e souber como realizá-la. Para exemplificar esse tipo de coerência, Fiorin e Savioli dão o seguinte exemplo:

Lá dentro havia uma fumaça que não deixava que víssemos ninguém.

Meu colega foi à cozinha, deixando-me sozinho. Fiquei encostado na parede da sala, observando as pessoas que lá estavam. Na festa, havia pessoas de todos os tipos: ruivas, brancas, pretas, amarelas, altas, baixas etc. (1995, p. 262).

Nesse texto, não há total coerência narrativa, porque o narrador-personagem afirma que $o$ ambiente enfumaçado não o deixa ver e, logo em seguida, diz que observa as pessoas. Ora, antes de identificar visualmente alguém, ele teria de adquirir competência para isso. Uma brisa entrando por uma janela repentinamente aberta resolveria o problema.

\section{A organização do espaço}

Importante em textos descritivos e narrativos, a coerência espacial diz respeito à forma como encadeamos os enunciados para, obedecendo a uma seqüência, auxiliar o leitor/ouvinte a compor o ambiente, o espaço. Observe:

O detetive Edmundo estava sentado no sofá de frente para a porta. A única porta da casa, pela qual passavam os convidados e por onde deveria passar José. De repente, um estrondo no jardim chama a atenção de todos. Edmundo continua serena e estranhamente sentado. Alguns convidados, no entanto, resolvem averiguar. Um homem dirige-se a uma das portas laterais, abre-a e observa os arredores. Outro vai até a porta dos fundos e gira a maçaneta... 
Percebe-se nitidamente a incoerência espacial: a única porta não permitiria que os convivas abrissem as portas laterais e dos fundos. Talvez as janelas.

\section{A organização do tempo}

Fiorin e Savioli afirmam que para haver coerência é necessário respeitar "as leis da sucessividade dos eventos", ou seja, os enunciados devem ser compatíveis do ponto de vista da localização no tempo. Para exemplificar esse tipo de coerência, os autores usam o seguinte exemplo:

Quando o professor entrou, ele já tinha posto o sapo na bolsa da colega e estava sentado tranqüilamente em seu lugar. O mestre pegou-o em flagrante, quando estava pondo o sapo na bolsa da colega.

Nesse trecho, há incoerência, "pois os enunciados são incompatíveis do ponto de vista da temporalização, já que o mesmo evento (pôr o sapo na bolsa da colega) é considerado, ao mesmo tempo, anterior (tinha posto) e concomitante (estava pondo) ao momento da entrada do professor". (2000, p.398)

\section{A concretização dos temas}

Diz respeito à maneira como concretizamos os temas em nossos textos. Se, para falar de paz, usássemos pombas brancas, pessoas se abraçando etc., seríamos coerentes. Mas, se citássemos brigas, guerras e prisões - a não ser que quiséssemos estabelecer uma oposição - seríamos incoerentes.

\section{Vejamos um exemplo:}

Os convidadố estavam todos vestidos a caráter: homens de fraque e mulheres com seus luxuosos vestidos de noite. Depois do sofisticadíssimo jantar servido em legítima porcelana chinesa e copos do mais puro cristal da Boêmia, todos se acomodaram nos canapés - com anjinhos talhados na madeira do recosto e garras de dragão nos pés - da sala de música para ouvir a esposa do anfitrião, João Alberto de
Azevedo Marques, exibir seus dotes musicais. Diziam que não eram poucos. Maria Cândida de Azevedo Marques, atendendo ao pedido carinhoso do marido, sentou-se ao piano alemão e começou a tocar Detalhes de Roberto Carlos. Todos ouviram atentamente a música.

Os elementos enumerados no texto concretizam o luxo e a sofisticação, por isso a música do "Rei" é incoerente. No ambiente requintado em que a soirée acontece, essa música só se justificaria se o narrador tivesse a intenção de ridicularizar as personagens, mostrando que o requinte é uma tinta que os reveste exteriormente. Não há, no entanto, nada no texto que nos permita fazer essa inferência, por isso Detalhes destoa dos outros elementos do texto.

\section{A argumentação}

A coerência argumentativa diz respeito às relações lógicas entre os enunciados do texto. Vejamos um exemplo:

Precisamos ser solidários e acabar com a pobreza que existe em todas as cidades brasileiras. Aqui na Lapa, por exemplo, ninguém suporta mais os mendigos e os moradores de rua. É preciso encontrar maneiras para que essa gente saia das ruas. Poderíamos mandar alguns deles para suas cidades de origem e proibir os migrantes de entrar na cidade.

Nesse raciocínio existem duas incoerências:

a) A solidariedade declarada inicialmente não está de acordo com as soluções para acabar com a pobreza: mandar os pobres embora e não deixá-los mais entrar nas cidades. Também seria incoerente alguém dizer que "todos têm direito à vida" e logo em seguida defender os terroristas que atacaram os Estados Unidos ou a matança de cidadãos civis que ocorre na guerra movida contra o Afeganistão.

b) $\mathrm{O}$ segundo problema refere-se ao exemplo: bairro da Lapa. O texto fala em cidades, por isso não poderia dar como exemplo um bairro. $\mathrm{O}$ raciocínio que levou a essa incoerência poderia 
ter sido este: "Toda cidade tem pobres. A Lapa tem pobres; logo, a Lapa é uma cidade." Pode-se perceber que há uma inadequação entre as afirmações anteriores e a conclusão, pois pode haver pobres em lugares que não são cidades, bem como existir cidades em que não haja pobres.

\section{O nível de linguagem}

Num texto, é preciso que a variante lingüística escolhida, o nível léxico e as estruturas sintáticas sejam compatíveis com a situação, o gênero do texto etc. Se a construção "arresolveu se casá" é perfeita para o samba de Sérgio Porto que analisamos anteriormente, não seria coerente no editorial de um jornal ou num artigo científico, a não ser que se quisesse exemplificar um determinado registro lingüístico ou essa "violação" viesse acompanhada de uma ressalva: "com perdão da palavra", "se me permitem o uso da palavra" etc. Observemos mais um exemplo:

Desejo agradecer, muito sensibilizado, por ter a oportunidade de falar nesta tão ilustre casa: o Congresso Nacional, um dos esteios da nossa já consolidada democracia. Valeu.

Gostaria de pedir que Vossas Excelências fizessem um esforço para considerar com rapidez os projetos que tratam da reformulação da carga tributária; alguns já tramitam nesta casa há vários anos. Não é possível que Vossas Excelências sejam insensíveis a essa situação a que o cidadão está submetido. É um absurdo, uma verdadeira sacanagem que o assalariado tenha de pagar mais imposto que os banqueiros sem-vergonha.

As palavras em destaque destoam do restante do vocabulário utilizado no texto; são incoerentes nesse tipo đé discurso e de situação, por mais que tenham sido usadas com seu sentido próprio façam parte de construções sintaticamente adequadas.

\section{A semântica}

A coerência semântica relaciona-se aos sig- nificados das palavras e sintagmas que constituem as frases. Por exemplo:

Entro no banho e depois de 10 minutos senti um cheiro de queimado, que ia se espalhando cada vez mais, onde eu fiquei petrificada e comecei a gritar.

Nessa frase, as palavras espalhando, petrificada e onde foram impropriamente empregadas. Espalhar significa difundir, alastrar. A impropriedade ocorre, porque alguém do banheiro não poderia sentir o cheiro de queimado se alastrar pela casa. $\mathrm{O}$ adjetivo petrificado opõe-se à ação de gritar: alguém petrificado não grita. $\mathrm{O}$ pronome relativo onde é comumente utilizado para retomar um antecedente que se refira a lugar. $\mathrm{Na}$ frase, onde não retoma nenhum antecedente, na verdade foi usado como conectivo que introduz uma conseqüência.

Cabe ainda uma observação quanto ao tempo verbal de entro (presente) senti, ia, fiquei (pretérito). Seria mais adequado usar o mesmo tempo.

\section{A sintaxe}

Diz respeito aos meios sintáticos usados para expressar a coerência semântica: conectivos, pronomes etc. No exemplo acima, o pronome onde poderia ser considerado um caso de incoerência sintática. Vejamos mais um exemplo:

$\mathrm{Na}$ verdade, essa falta de comer, de bebida, seja porque não se tem dinheiro, está todo mundo sem trabalho, não podendo nem ficar em pé por muito tempo porque sente tontura.

Nessa frase, há vários problemas:

a) Não há paralelismo sintático em "falta de comer, de bebida", pois comer é um verbo e bebida, um substantivo. A construção seria paralela, se disséssemos "falta de comer, de beber" ou "falta de comida, de bebida".

b) A conjunção seja, em "seja porque não se tem dinheiro", tem valor alternativo e, por isso, esperamos que se enumere pelo menos mais uma 
razão: "seja porque não se tem dinheiro, seja porque não se tem crédito". Talvez pudéssemos compreender "está todo mundo sem trabalho" como a outra alternativa; nesse caso, não se deveria omitir a conjunção: "seja porque não se tem dinheiro, seja porque está todo mundo sem trabalho".

c) O sujeito essa falta de comer não está ligado a um predicado, por isso a frase está fragmentada.

\section{Conclusão}

Esperamos que os exemplos analisados tenham sido suficientes para mostrar que a coerência surge de complexas relações: entre enunciados, textos, texto e contexto, texto e gênero, texto e o mundo, texto e os leitores. Sem que a situação de comunicação seja explicada, sem respeitar as regras do gênero, sem um título adequado, sem compatibilidade ou adequação dos enunciados, não há texto coerente. A construção da coerência também depende da relação produtor/receptor. Não há via de mão única nesse caso. Se o produtor do texto domina regras e tem conhecimentos que o leitor desconhece, o texto parecerá absurdo e sem sentido. Por isso, é necessário que o conhecimento seja comum: não há bons leitores, se não houver bons escritores e vice-versa.

\section{REFERÊNCIAS BIBLIOGRÁFICAS}

BANDEIRA, Manuel. Estrela da Vida Inteira. Rio de Janeiro: José Olympio, 1988.

DIAS, Gonçalves. Poesia e prosa completas. Rio de Janeiro: Nova Aguilar, 1998.

FIORIN, José Luiz; SAVIOLI, Francisco Platão. Para entender o texto. São Paulo: Ática, 1995.

. Lições de texto: leitura e redação. São Paulo: Ática, 2000.

KOCH, Ingedore Villaça; TRAVAGLIA, Luiz Carlos. A coerência textual. São Paulo: Contexto, 1997. (Repensando a Língua Portuguesa).

Texto e coerência. São Paulo: Cortez, 1999.

LA FONTAINE. Fábulas. São Paulo: Paumape, 1993.

PAES, José Paulo. Um por todos: poesia reunida. São Paulo: Brasiliense, 1986.

SOARES, Juarez. "Loucura". Terra Esportes, 2001. Disponível na internet: www.terra.com.br/esportes/colunistas/2001/07/19/002.htm. 